(C2007 IEEE. Personal use of this material is permitted. However, permission to reprint/republish this material for advertising or promotional purposes or for creating new collective works for resale or redistribution to servers or lists, or to reuse any copyrighted component of this work in other works must be obtained from the IEEE. 


\title{
Optimal Design and Modeling of Stand-Alone Hybrid PV-Wind Systems
}

\author{
M. Mousavi Badejani, M.A.S. Masoum and M. Kalanta
}

\begin{abstract}
This paper presents the development of an effective approach for design, simulation and analysis of hybrid PV-wind generating systems which is based on discrete optimization of cost function and balance of energy. The total capacities of renewable systems are computed based on the estimated annual power consumption, average wind speed and sun radiation. To improve the performance of the system under different environmental conditions, Maximum Power Point Tracking (MPPT) of the photovoltaic system and blade angle pitch control of wind turbines are included. A discrete cost function is defined and optimized to determine optimal design options with minimum number of PV and wind units capable of supporting the yearly demand load. Finally, system simulation and energy balance calculations over a period of three years are used to compensate for design errors caused by the discrete nature of the optimization approach. Main contributions are the inclusion of renewable systems configurations, capacities, environmental factors and maximum power point tracking in the optimization procedure.
\end{abstract}

Index Terms-Renewable systems, Hybrid, PV farm, wind turbine, cost function and energy balance.

\section{INTRODUCTION}

$\mathrm{D}$ ue to accessibility and lower cost of renewable energy resources in deserted and far-flung areas, as compared to the conventional solutions, their applications in standalone systems have been increasing. Considering the rapid consumption of fossil energy sources, the hybrid renewable systems are about to have great share in future's energy supply [1]. Alternative energy sources are inherently non-polluting, free in their availability, and continuous [2]. However, their applications in conventional distribution systems are limited due to high initial cost and reliability issues [3-22].

An easy and effective approach in utilizing solar energy is to convert it directly to electrical energy using Photovoltaic (PV) technology [4]. According, it is anticipated that PV systems will become one of the main energy recourses to fulfill the global energy requirement by the end of this century [5]. Other methods such as wind power plants, fuel cells batteries, and solar-heat plants are also considerable and are usually

Mehdi Mousavi Badejani and Mohsen Kalanta are with the Center of Excellence for Power Systems Operation \& Automation, Department of Electrical Engineering, Iran University of Science \& Technology, Narmak, Tehran, IRAN, 16846.

Mohammad A.S. Masoum is with the Department of Electrical Engineering, Curtin University of Technology, Perth, WA6845, Australia (e-mail: m.masoum@curtin.edu.au). combined with PV units in order to increase system reliability [6]. An important and growing concern has been the approach used to design and control renewable hybrid systems. Different methods for modeling and controlling power production systems are possible by combination of two or more renewable energy systems [7]. The most important and considerable issues about these environmentally friendly systems are their cost and reliability [8].

Nowadays the PV and wind generators are widely use in many applications such as water pumping, illumination [9], electricity supply in outlying areas [10] and supplying communication systems. To include power shortage capability, diesel generators may be used in parallel [11]. Considering the importance of synchronized operation between diesel generators and renewable supply system, the maintenance costs will be noticeable [12]. However, utilization of renewable hybrid systems offers more reliability than diesel generators, photovoltaic or wind systems [13].

This paper presents an effective methodology for design and modeling of hybrid wind-photovoltaic systems including their planning and analysis using discrete optimization of cost function and energy balance calculation. To extract the maximum available energy under different environmental conditions, blade angle pitch control of wind turbines [14] and voltage-based maximum power point tracking (VMPPT) of PV system [15-16] are implemented. The average power produced by each PV unit and wind turbine is estimated based on statistical information collected during 13 years. The proposed hybrid structure will be determined by defining and optimizing a cost function and performing energy balance calculations for a period of three years.

\section{HYBRID PV-WIND SYSTEM}

The proposed hybrid wind-photovoltaic system is shown in Figure 1. An induction generator is used in conjunction with the wind turbine due to its robustness, low cost, low maintenance and greater power-weight ratio (as compared with DC and permanent magnet machines) [14]. To extract the maximum available energy under different environmental conditions, a voltage-based maximum power point racking (VMPPT) unit for the PV system is included [15-16]. 


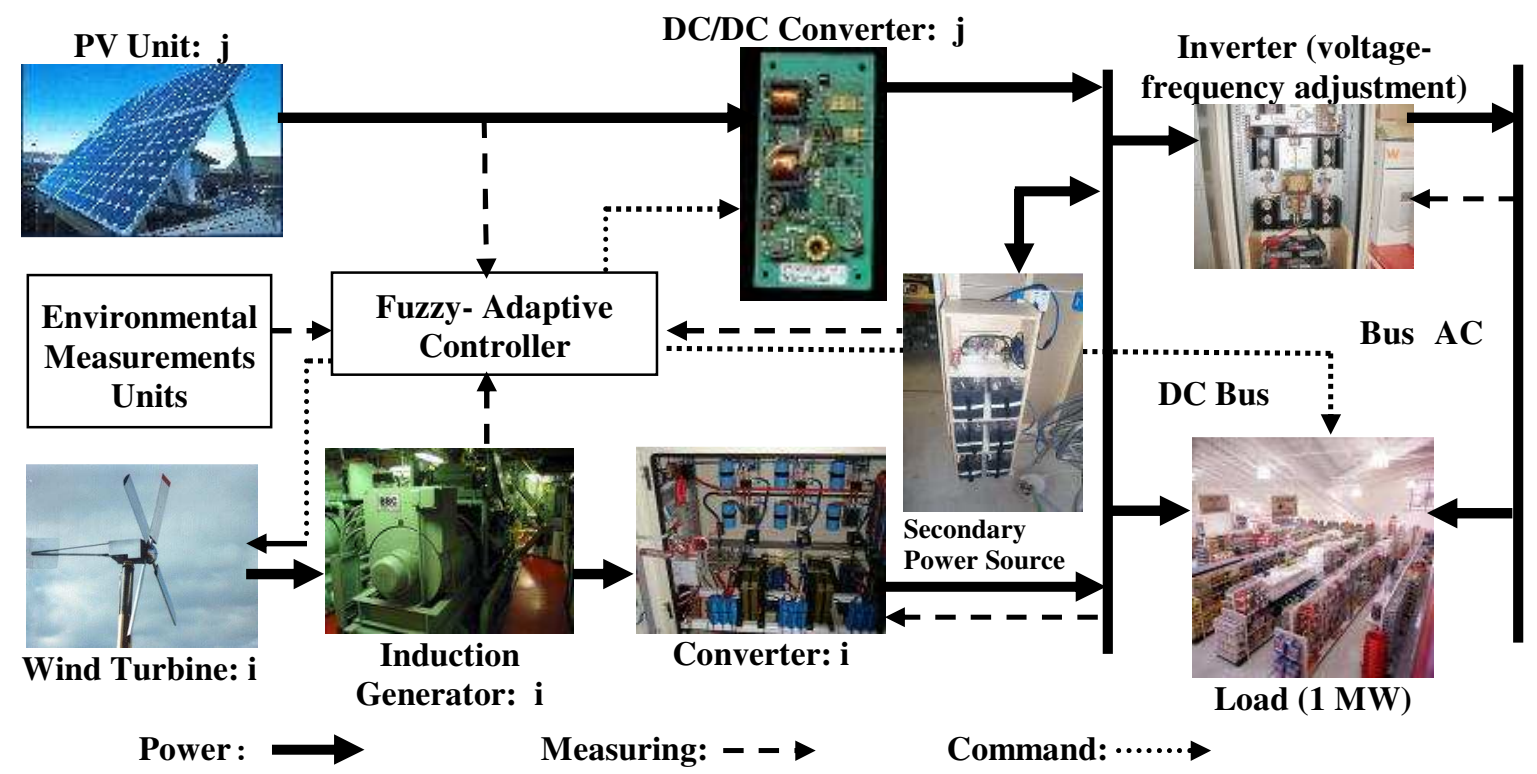

Fig. 1. Overall Block Diagram of Stand-alone PV-Wind System

Blade angle pitch control of turbines is used to extract the maximum available wind power which is transferred by the induction generator and three-phase bridge rectifier to the common DC bus. To facilitate system application, an AC bus is also included in the design. A secondary power source (battery unit) is also included to provide required additional power during excessive and emergency loading conditions. System control and synchronization between the renewable energy units under different environmental and DC/AC loading conditions is performed using a control unit which is responsible for setting the optimal operating points of $\mathrm{PV}$, wind and load units.

\section{SySTEM STRUCTURE AND MODELING}

Combination of PV farms, wind units and the secondary power supply (Fig. 1) increases the overall reliability during different environmental conditions. In this section, the ultimate structure and size of each unit will be selected by specifying the environmental factors and calculating the average power produced by each wind and solar unit. The final combination, type and size of different units will be determined by defining a cost function and solving a discrete optimization problem.

\section{A. PV Unit Modeling}

The equivalent circuit of a solar-PV cell is shown in Figure 2. Neglecting the parallel resistance $R_{p}$, the general equation of a solar cell is:

$I_{\mathrm{pv}}=\mathrm{I}_{\mathrm{ph}}-\mathrm{I}_{\mathrm{o} 1}\left\{\exp \left(\frac{\mathrm{V}_{\mathrm{pv}}+\mathrm{IR}_{\mathrm{s}}}{\mathrm{K} \mathrm{T}}\right)-1\right\}$

$-I_{\mathrm{o} 2}\left\{\exp \left(\frac{\mathrm{V}_{\mathrm{pv}}+\mathrm{IR}_{\mathrm{s}}}{2 \mathrm{KT}}\right)-1\right\}-\frac{\mathrm{V}_{\mathrm{pv}}+\mathrm{IR}_{\mathrm{s}}}{\mathrm{R}_{\mathrm{p}}}$.

whre $I_{p h}$ is the cell current (proportional to radiation level), $q$ is the electric charge of a single electron, $\mathrm{T}$ is the absolute temperature in Kelvin, $\mathrm{K}$ is Boltzmann constant, $\mathrm{I}_{\mathrm{o} 1}$ and $\mathrm{I}_{\mathrm{o} 2}$ are the first and second order cell reverse saturation currents, respectively.

Equation 2 represents the voltage-current characteristic of a photovoltaic panel consisting of $\mathrm{N}_{\mathrm{p}}$ parallel branches (with $\mathrm{N}_{\mathrm{s}}$ serial cells in each branch) ( $\alpha$ is rectification coefficient depending on cell).

$\mathrm{v}_{\mathrm{PV}}=\frac{\mathrm{N}_{\mathrm{S}}}{\lambda} \ln \left(\frac{\mathrm{N}_{\mathrm{P}} \mathrm{I}_{\mathrm{ph}}-\mathrm{i}_{\mathrm{pv}}}{\mathrm{N}_{\mathrm{P}} \mathrm{I}_{0}}+1\right)-\frac{\mathrm{N}_{\mathrm{S}}}{\mathrm{N}_{\mathrm{P}}} \mathrm{R}_{\mathrm{s}} \mathrm{i}_{\mathrm{pv}}$

where $\lambda=\mathrm{q} / \alpha \mathrm{KT}$ is the cell material coefficient, $\alpha$ is cell rectification coefficient and other parameters are provided in Table 1 for the silicon PV panels manufactured by the Iranian Optical Fiber Fabrication Co. (OFFC). The voltage-current characteristic of one OFFC PV panel $\left(\mathrm{N}_{\mathrm{p}}=1\right.$ and $\left.\mathrm{N}_{\mathrm{s}}=36\right)$ at 25 degree Celsius is

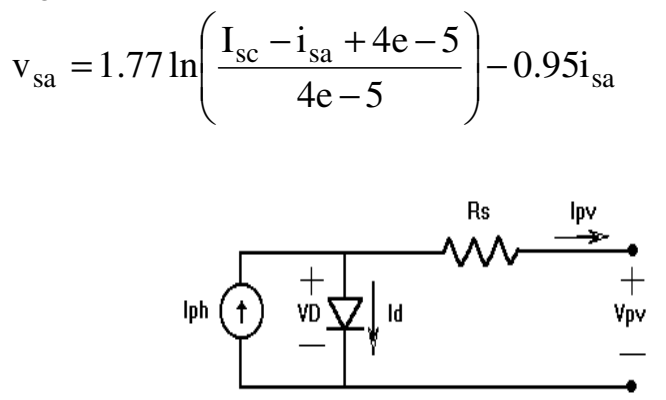

Fig. 2. Equivalent circuit of solar cells

The measure and computed (Eq. 3) v-i and P-i characteristics power of a typical OFFC silicon PV panel at different temperatures and radiation levels are shown in Figure 3. 


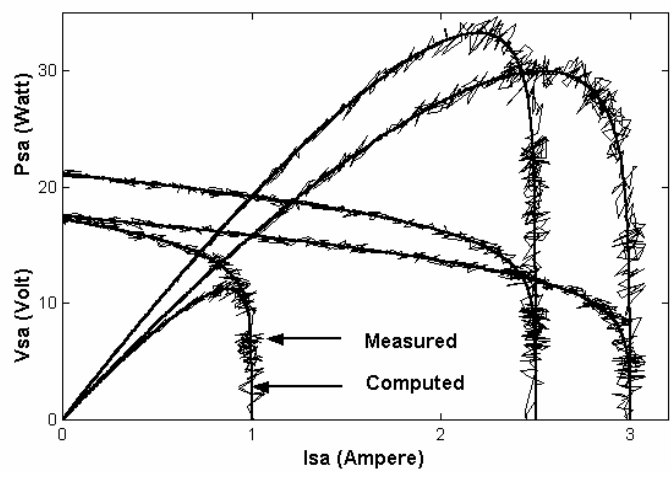

Fig. 3. Computed (Eq. 2) and measured nonlinear V-I and P-I characteristics of one OFFC silicon solar panel (Table 1).

TABLE 1.

SPECIFICATIONS OF SILICON PV PANELS MANUFACTURED BY OFFC

\begin{tabular}{|l|l|}
\hline Cell dimensions & $10 \mathrm{~cm}$ by $10 \mathrm{~cm}$ \\
\hline $\begin{array}{l}\text { Current temperature } \\
\text { coefficient }\end{array}$ & $\alpha_{\mathrm{I}}=0.002086 \mathrm{~mA} /{ }^{\circ} \mathrm{C}$ \\
\hline $\begin{array}{l}\text { Voltage temperature } \\
\text { coefficient }\end{array}$ & $\alpha_{\mathrm{V}}=0.0779 \mathrm{mV} /{ }^{\circ} \mathrm{C}$ \\
\hline Reverse saturation current & $\mathrm{I}_{0}=0.5 \times 10^{-4} \mathrm{~A}$ \\
\hline Short-circuit cell current & $\mathrm{I}_{\mathrm{SC}}=2.926 \mathrm{~A}$ \\
\hline Cell resistance & $\mathrm{R}_{\mathrm{S}}=0.0277[\Omega]$ \\
\hline Cell material coefficient & $\lambda=0.049[1 / \mathrm{V}]$ \\
\hline
\end{tabular}

To extract the maximum available power from solar panels, electrical and mechanical maximum power point tracking (MPPT) is performed:

Electrical MPPT: in this paper the voltage-base maximum power point tracking (VMPPT) method is implemented [1516] where the maximum solar-array power is calculated using its open-circuit voltage (Eq. 4). A practical approach is to measure the open-circuit PV panel voltage and calculate the system optimal operating voltage as [15]

$\mathrm{V}_{\mathrm{OC}}=\frac{\mathrm{KT}}{\mathrm{q}} \operatorname{Ln}\left(\frac{\mathrm{I}_{\mathrm{sc}}}{\mathrm{I}_{\mathrm{O}}}+1\right)$

Mechanical MPPT: there are different control approaches to mechanically trace the sun radiation (Fig. 4). In this paper, the fixed angle control approach is implemented (Fig. 4-d). The sun radiation angel on the $\mathrm{n}^{\text {th }}$ day of year is calculated by below given equation:

$\theta=A \sin \left[\sin (\delta) \sin (\varphi)+\cos (\delta) \cos (\varphi) \cos \left(\mathrm{t}_{\mathrm{m}}\right)\right]$

$\delta=A \sin [\sin (\alpha) \sin (n / 360)]$

where $\varphi$ is the latitude of PV panel location, $t_{m}$ is hourly time and $\alpha$ is the obliquity of the ecliptic (23.4523 degree). Eq. 5 provides the daily average power produced by each PV unit.
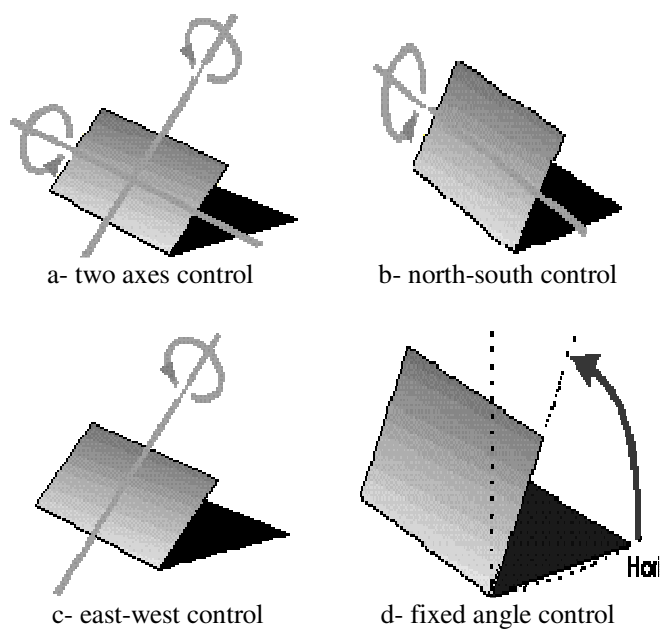

Fig. 4. Control methods for mechanical MPPT

\section{B. Wind Unit Modeling}

The power produced by wind units depends on environmental factors and its instantaneous value can be calculated as:

$\mathrm{P}_{\mathrm{w}}=\frac{1}{2} \rho \mathrm{V}^{3} \mathrm{C}_{\mathrm{p}}$

where $\mathrm{C}_{\mathrm{p}}=\frac{1}{2}\left(1+\frac{\mathrm{V}_{\mathrm{C}}}{\mathrm{V}}\right)\left[1-\left(\frac{\mathrm{V}_{\mathrm{C}}}{\mathrm{V}}\right)^{2}\right], \rho$ is the air density, $\mathrm{V}$ is wind

speed and $\mathrm{V}_{\mathrm{C}}$ is the turbine low cut speed. In other words, wind output power is proportional to the first wind speed and can be calculated as:

$P_{W}(v)= \begin{cases}\left(\frac{v-v_{c}}{v_{r}-v_{c}}\right) P_{r} & v_{c} \leq v \leq v_{r} \\ P_{r} & v_{r} \leq v \leq v_{f} \\ 0 & \text { otherwise }\end{cases}$

where $\mathrm{V}_{\mathrm{r}}$ and $\mathrm{P}_{\mathrm{r}}$ are turbines nominal speed and power, respectively, and $v_{r}$ is the turbine high cut speed. The technical properties of the turbine unit are listed in Table 2.

Statistical information used in this paper has been collected by Valkenburg forecast station (the United-States Weather Forecast Station No. 210, 1982-1995) in hourly reports, which is located 10 meters above free sea surface. The average wind speed curve over 13 years is used as an estimation of average yearly wind. The average power produced over one hour by a single wind unit is calculated based on the equation provided in the last row of Table 2. The statistical means and average wind speed is shown in Figure 5. 


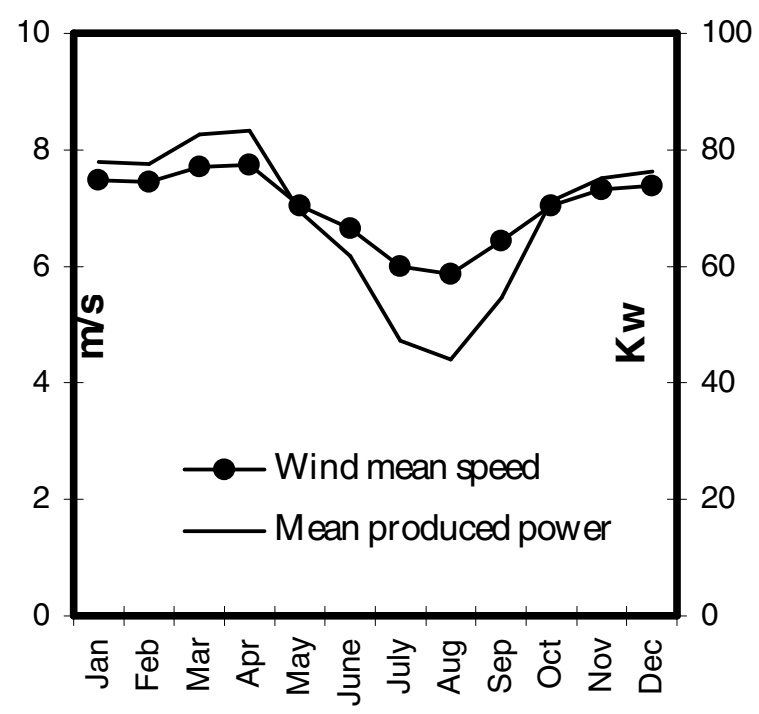

Fig. 5. Statistic data of wind over 13 years

TABLE II.

TECHNICAL PROPERTIES OF THE TURBINE UNIT

\begin{tabular}{|l|l|}
\hline Manufacture, type & Vestas225-29, lateral axes \\
\hline Rated power & $225 \mathrm{KW}$ (in rated speed) \\
\hline $\begin{array}{l}\text { Rated, cut-in and cut-out } \\
\text { speeds }\end{array}$ & $14.5,2.3,39.3(\mathrm{~m} / \mathrm{s})$ \\
\hline Output & $480 \mathrm{VAC} / 3-$ phase $/ 60 \mathrm{HZ}$ \\
\hline $\begin{array}{l}\text { Statistic function: output } \\
\text { power (KW) - mean wind } \\
\text { speed(m/s) }\end{array}$ & $=21.09 \mathrm{v}_{\mathrm{r}}-79.38$ \\
\hline
\end{tabular}

The average power produced by each wind-turbine is

$$
\mathrm{P}_{\mathrm{W}, \text { avg }}=\int_{0}^{\infty} \mathrm{P}_{\mathrm{w}} \mathrm{f}(\mathrm{v}) \mathrm{dv}
$$

where $f(v)$ is the probability density function of wind speed which can be determined via statistical information. Weber function is the best density function for modeling the wind speed [16].

$f(v)=\frac{k}{c}\left(\frac{v}{c}\right)^{k-1} \exp \left[-\left(\frac{v}{c}\right)^{k}\right](k>0, v>0, c>0)$

where $\mathrm{v}$ is wind speed, $\mathrm{c}=7.8 \mathrm{~m} / \mathrm{s}$ is gauge parameter and $\mathrm{k}=1.99 \mathrm{~m} / \mathrm{s}$ is the shape parameter. Values of $\mathrm{c}$ and $\mathrm{k}$ are estimated based on the statistical computations. $\mathrm{P}_{\mathrm{w}}$ is the function of power produced by turbines under various given speeds (Eq. 6).

\section{Load and Power Electronic Components}

In this paper, a constant load density function is assumed which is bounded between the maximum and minimum powers:
$f_{L}(p)= \begin{cases}\frac{1}{P_{\text {max }}-P_{\text {min }}} & P_{\text {min }}<p<P_{\text {max }} \\ 0 & \text { other wise }\end{cases}$

Power electronic devices are assumed to have constant efficiencies and current harmonics at the AC sides are neglected. Due to the hybrid nature of the design with two secondary charging units, the relative DOD (depth of discharge) is lower than single-source (photovoltaic or wind) systems which will result in longer expected life time.

\section{SYSTEM DESIGN AND OPTIMIZATION}

The system life time is considered to be 10 years. General information about indicated location is listed in Table 3. Above the atmosphere, average vertical radiation power is equal to $1352 \mathrm{~W} / \mathrm{m}^{2}$ and on the earth this value drops to 1001 $\mathrm{W} / \mathrm{m}^{2}$ (assuming an output efficiency of $74 \%$ for atmosphere [17]). Therefore, to supply 40 kilowatts of average annual power by each photovoltaic unit, $1221.5 \mathrm{~m}^{2}$ of effective area is required that can be delivered by $5221 \mathrm{PV}$ panels (Eqs. 3-5). Each wind-unite produces 225 kilowatts at nominal speed. Considering the average wind speed (Table 3), the average produced power is $68.461 \mathrm{~kW}$ (Eqs. 7-9).

TABLE III.

GEOGRAPHICAL INFORMATION OF SYSTEM LOCATION

\begin{tabular}{|l|l|}
\hline Latitude & 40 degree, North \\
\hline Annual mean of daily sun angle & 15.38 degree \\
\hline $\begin{array}{l}\text { Mean produced power per PV } \\
\text { square meter }\end{array}$ & $32.7 \mathrm{~W}$ \\
\hline Annual mean of wind speed & $7.01 \mathrm{~m} / \mathrm{s}$ \\
\hline Mean variation in wind direction & 30 degree \\
\hline
\end{tabular}

Most battery models assume linear characteristic and neglect the nonlinear and complicated nature of the electro-chemical process [18]. In order to fulfill the power demand and to attain lower price and longer life time, lead-acid batteries $(120 \mathrm{~V}$, 10kA-h) with relatively low DOD of $40 \%$ are selected.

Two types of loads (AC and DC) with total average power of 1 MW and the power profile of reference [16] are considered (Fig.6).

Based on the above-mentioned statistics, the load may be supplied by either PV or wind systems with the following specifications:

- A Photovoltaic system consisting of $25\left(\mathrm{n}_{\mathrm{PV}-\max }=25\right)$ PV units (40 kW/unit).

- A wind system consisting of $15 \quad\left(\mathrm{n}_{\text {wind-max }}=15\right)$ turbines (225 kW/turbine).

- A hybrid Photovoltaic -wind system consisting of optimum numbers of PV and wind units.

The first two approaches are not recommended due to low reliability and high costs as compared to the hybrid configuration. 


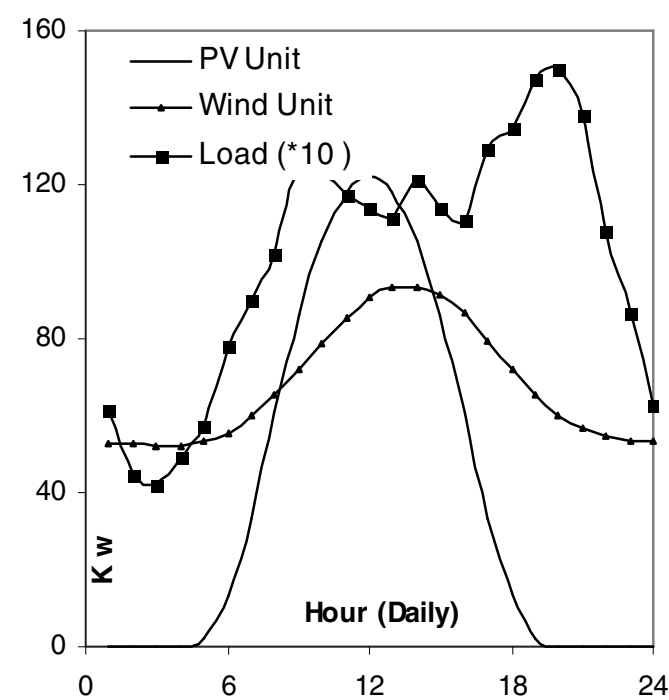

Fig. 6. Average power produced by each renewable unit and the total annual load [16]

In order to determine the optimum number of the PV, wind, battery and surplus produced power, the following discrete cost function is defined and optimized:

$$
\begin{aligned}
& \mathrm{CF}=\mathrm{CF}_{\mathrm{PV}}+\mathrm{CF}_{\text {Wind }}+\mathrm{CF}_{\mathrm{Bat}}-\mathrm{CF}_{\text {Add }} \\
& \mathrm{CF}_{\mathrm{PV}}=\frac{\mathrm{n}_{\mathrm{PV}} \times \mathrm{k}_{\mathrm{PV}}\left(\mathrm{P}_{\mathrm{Avg}-\mathrm{PV}}\right) \mathrm{t}}{\left(\eta_{\mathrm{DC}} / \mathrm{DC}\right)\left(\mathrm{k}_{\mathrm{Acc}-\mathrm{PV}}\right)}
\end{aligned}
$$

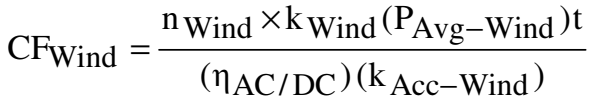

$$
\begin{aligned}
& \mathrm{CF}_{\mathrm{PV}}=\mathrm{k}_{\text {Batt }} \times \mathrm{C}_{\text {Batt-Max }} \\
& \mathrm{CF}_{\text {Add }}=\mathrm{k}_{\text {Add }} \times \mathrm{p}_{\text {Add }} \times \mathrm{t}
\end{aligned}
$$

In this expression, $\mathrm{t}$ is the operating time, $\mathrm{k}$ coefficients in numerators and denominators are statistical production cost and statistical source accessibility expense, respectively, $\mathrm{n}$ is number of each unit, $\eta$ is the average converters efficiency, $\mathrm{C}_{\mathrm{Batt}-M a x}$ is the maximum required battery capacity under all operating conditions and $\mathrm{P}_{\text {Add }}$ is the surplus produced power of each structure (positive energy balance) with usual electricity cost.

Discrete optimization is performed by developing a MatLab software program that increases the number PV units from 1 to $\mathrm{n}_{\mathrm{PV}-\max }$, calculates the number of required wind and battery units, computes and stores the corresponding cost functions (Eq. 11) for each case (Fig. 7). According to this analysis, the optimum combination of PV units and wind-turbines consists of $10 \mathrm{PV}$ units and 9 wind-turbines. In this case the secondary source capacity is $2760 \mathrm{Mwh}$ for preserving required energy. Energy balance has been implemented for the year 1989 using the actual statistical information and the accumulated surplus energy (that can be preserved or consumed by other users) has been derived, as shown in Fig. 8. Based on this information, during 3 months of year (e.g., winter time) the energy balance is negative while during the remaining months, there is about $90 \mathrm{MW}$ of excess energy.

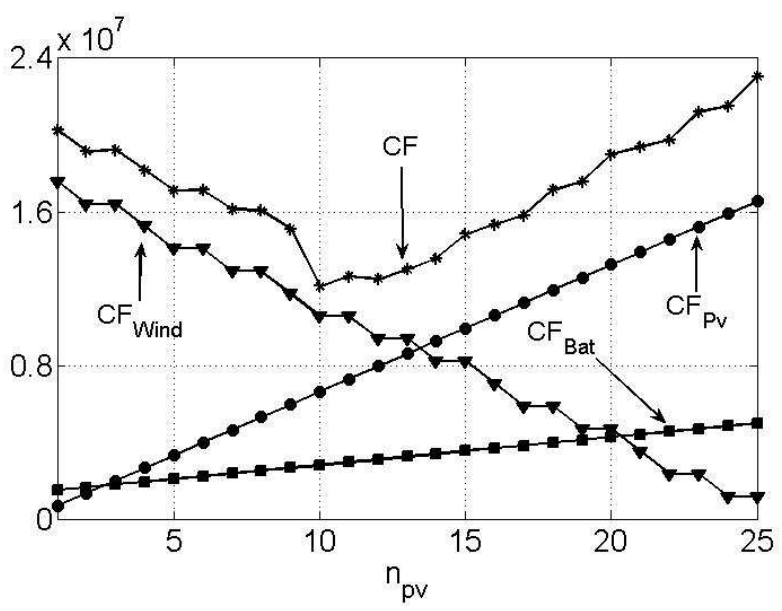

Fig. 7. Computed cost functions (Eq. 11) versus the number of PV units

In order to determine the optimal number of PV and wind units for the corresponding load and geographical conditions, simulations have been performed to plot the energy balance function for three years with different number of renewable units, as shown in Fig. 9:

- With the present state of the system (e.g., $10 \mathrm{PV}$ and 9 wind units), the 3 year energy balance appears to be -2000 MWh (Fig. 9, Case 1).

- This negative balance can not be compensated by the addition of only one photovoltaic unit (Fig. 9, Case 2) or one wind turbine (Fig. 9, Case 3).

- However in case of including two additional photovoltaic units (Fig. 9, Case 4) or two additional wind turbines (Fig. 9, Case 5) or one additional unit of each renewable system, acceptable energy balance compensation will be maintained.

- Based on the cost function of Figure 7, increasing the number of photovoltaic units is more suitable. Therefore, the optimal proposed design consisits of $12 \mathrm{PV}$ units and 9 wind turbines.

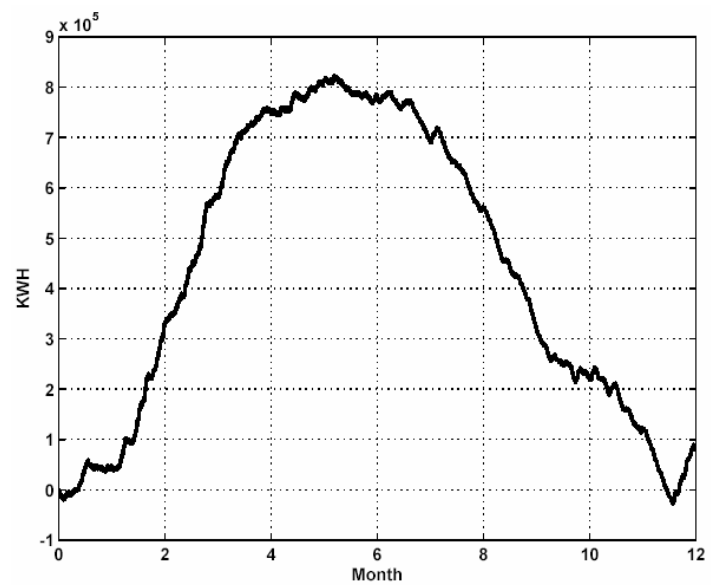

Fig. 8. Energy balance in 1989 


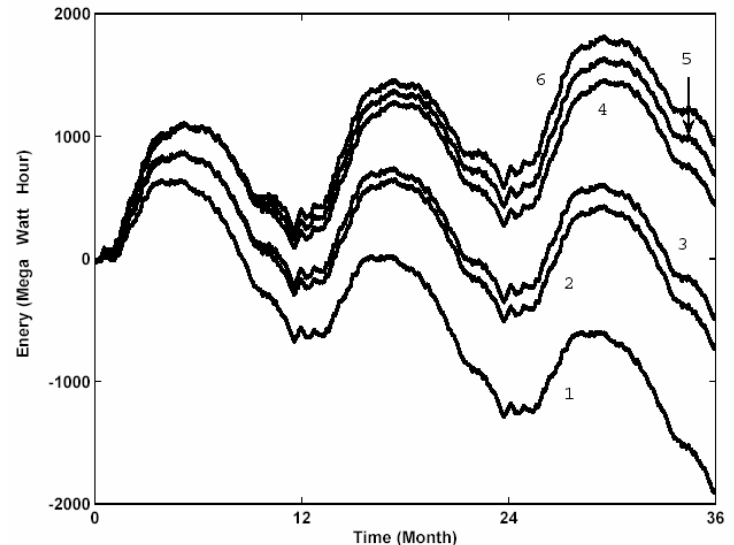

Fig. 9. Computed energy balance in three consecutive years for different number of PV units and wind turbine.

\section{CONCLUSIONS}

This paper presents an effective approach for optimum design, modeling and analysis of stand-alone hybrid PV-wind energy systems.

Considering the load demand and environmental conditions, an appropriate hybrid structure is selected (Fig. 1). Detailed modeling and analysis of system components including PV units, wind turbines, the secondary source and load profile are presented (Eqs. 1-10). Furthermore, the average power produced by each PV unit and wind turbine is estimated according to the consecutive statistical information collected during 13 years (Fig. 5). In these structures the power produced by each PV and wind unit, as well as, load demand and battery capacity is analyzed (Fig. 6).

In order to determine the optimum number of PV and wind units, real yearly statistical data are used, a cost function is defined (Eq. 11), optimized and utilized to select the best hybrid structure that can fulfill the required load power demand. Finally, system simulation and energy balance calculations over a period of three years are used to compensate for design errors caused by the discrete nature of the optimization approach.

\section{REFERENCES}

[1]. Energy Universal Council, "Energy for next race", Translated to Persian by D. Foroghi, 1996.

[2] M.A. Green, "Solar Cells: Operating Principles, Technology and System Applications", Prentice-Hall, Inc.

[3]. R. Hill and A.E. Baumann, "Environmental costs of photovoltaics", Science, Measurement and Technology, IEE Proceedings, Vol.140, Issue 1, pp.76 - 80, Jan. 1993.

[4] M.A.S. Masoum and S.M. Mousavi, "Analysis of photovoltaic system with DC/DC converters using PWM and sliding controllers", International Journal of Renewable Energy Engineering, Vol. 4, No. 1, April 2002.

[5]. K. Ogawa and F. Aratani, "Present status of research and development of PV technology in Japan", Twenty-Ninth IEEE Conference on Photovoltaic Specialists, pp. 3-7, 19-24 May 2002.

[6]. Y.-M. Chen and Y.-C. Liu., "Development of multi-port converters for hybrid wind-photovoltaic power system", IEEE Proc. on Electrical and Electronic Technology, Vol. 2, pp.804 - 808, 19-22 Aug. 2001.
[7] M.A.S. Masoum and S.M. Mousavi, "Theoretical AND EXPERIMENTAL ANALYSIS OF PHOTOVOLTaIC System WITH DC/DC Converter USING SLIDING CONTROller", the $10^{\text {th }}$ Iranian CONFERENCE ON ELECTRICAL ENGINEERING, ICEE 2002.

[8] K. Stokes and J. Bigger, "Reliability, cost, and performance of PV-powered water pumping systems: a survey for electric utilities", IEEE Trans. on Energy Conversion, Vol.8, Issue 3, pp.506 - 512, Sept. 1993.

[9]. T.-F. Wu, C.-H. Chang and Y.-H. Chen, "A fuzzy-logiccontrolled single-stage converter for PV-powered lighting system applications", IEEE Trans. on Industrial Electronics, Vol.47, Issue 2, pp.287 - 296, April 2000.

[10]. N. Jenkins, "Photovoltaic systems for small-scale remote power supplies”, IEEE Conf. on Power Engineering, Vol.9, Issue 2, pp.8996, April 1995.

[11]. E.S. Abdin, A.M. Osheiba and M.M. Khater, "Modeling and optimal controllers design for a stand-alone photovoltaic-diesel generating unit", IEEE Trans. on Energy Conversion, Vol.14, Issue 3, pp.560 - 565, Sept. 1999.

[12]. A.C. Saramourtsis, A.G. Bakirtzis, P.S. Dokopoulos and E.S. Gavanidou, "Probabilistic evaluation of the performance of winddiesel energy systems", IEEE Trans. on Energy Conversion, Vol.9, Issue 4, pp.743 - 752, Dec. 1994.

[13]. J. Eto, V. Budhraja, C. Martinez, J. Dyer and M. Kondragunta, "Research, development, and demonstration needs for large-scale, reliability-enhancing, integration of distributed energy resources", $33^{\text {rd }}$ Annual Hawaii International Conference, pp.7, 4-7 Jan. 2000.

[14]. S.M. Alghuwainem, "Speed Control of a PV Powered DC Motor Driving a Self-Excited Three-Phase Induction Generator for Maximum Utilization Efficiency", IEEE Trans. on Energy Conversion, Vol.11, No.4, Dec. 1998.

[15]. M.A.S. Masoum, H. Dehbonei, and E.F. Fuchs, "Theoretical and Experimental Analysis of Photovoltaic Systems with Voltage and Current-Based Maximum Point Tracking”, IEEE Trans. on Energy Conversion, Vol.17, No.4, pp.514-522, Dec. 2002.

[16]. M.A.S. Masoum, S.M.M. Badejani, and E.F. Fuchs, "Microprocessor-controlled new class of optimal battery chargers for photovoltaic applications" IEEE Trans. on Energy Conversion, Volume 19, Issue 3, Sept. 2004 Page(s): 599 - 606, Digital Object [16] Identifier 10.1109/TEC.2004.827716.

[17]. M. R. Patel, "Wind and solar power systems", U.S. Merchant Marine Academy, Kings Point, New York.

[18]. Iowa Energy Center, www.energy.iastate.edu.

[19]. Y.H. Kim and H.D. Ha, "Design of Interface Circuit with Electrical Battery Models", IEEE Trans. on Industrial Electronics, Vol.44, No.1, pp. 81-86, Feb. 1997.

[20]. A.N. Celik, "Techno-economic analysis of autonomous PVwind hybrid energy systems using different sizing methods", Energy Conversion and Management, Vol. 44, No.12, pp1951-1968, 2003.

[21]. A. Bin, Y. Hongxing, S. Hui and L. Xianbo, "Computer Aided Design for PV/Wind Hybrid system", Proceedings of $3^{\text {rd }}$ World Conference on Photovoltaic Energy Conversion, Vol.3, pp.24112414, 2003.

[22]. S. Ashok, "Optimized model for community-based hybrid energy system", Renewable Energy, Vol.32, No.7, pp. 1155-1164, 2007. 